\title{
VALIDATION OF SMARTPHONE FREE HEART RATE MONITORING APPLICATION DURING TREADMILL EXERCISE
}

\author{
VALIDAÇÃO DE APLICATIVO GRATUITO DE SMARTPHONE PARA MONITORAMENTO DAFREQUÊNCIA \\ CARDÍACA DURANTE EXERCICIO EM ESTEIRA
}

Original Article ARTIGO ORIGINAL Artículo Original

\author{
VALIDACIÓN DEAPLICACIÓN GRATUITA DE SMARTPHONEPARA MONITORIZACIÓN DE LA FRECUENCIA \\ CARDÍACA DURANTEEJERCICIO EN CINTA
}

Zulkarnain Jaafar ${ }^{1}$
(Physician)
Aravind Kumar Murugan' ${ }^{1}$
(Physician)

1. Sports Medicine Unit, Faculty of Medicine, University of Malaya, 50603, Kuala Lumpur.

\section{Correspondence}

Zulkarnain Jaafar

Sports Medicine Unit, Faculty of Medicine, University of Malaya, 50603, Kuala Lumpur. Malaysia. zulkarnainj@um.edu.my

\begin{abstract}
Objective: The number of people participating in leisure sports activities and amateur competitions has been rising sharply. Free smartphone heart rate monitoring applications are readily available for use; however, information on their accuracy during exercise is still limited. Therefore, the purpose of our study was to validate a smartphone free heart rate monitoring application during treadmill exercise in healthy individuals. Methods: This was a prospective experimental study testing the free heart rate app 'INSTANT HEART RATE: AZUMIO'Twentyseven healthy participants were requested to perform the treadmill task with four different workloads: walking at $2.0 \mathrm{mph}$, walking at $3.5 \mathrm{mph}$, jogging at $4.5 \mathrm{mph}$ and running at $6.0 \mathrm{mph}$. Participants had to perform the exercises for 3 minutes for each workload, and heart rates were recorded using the smartphone app and ECG at rest, during the exercise and recovery periods at each 60-second interval. Results: Heart rates measured using the free smartphone app at rest, walking at $2.0 \mathrm{mph}$, brisk walking at $3.5 \mathrm{mph}$, slow jogging at $4.5 \mathrm{mph}$ and recovery stage were accurate with correlation coefficient value $\geq 0.95$ and standard error of estimate $<1 \mathrm{bpm}$. However, the correlation values during running at $6 \mathrm{mph}$ were inconsistent with a standard error of estimate $>5 \mathrm{bpm}$. Conclusion: The free smartphone app that we tested accurately estimates heart rate at rest, during low to moderate intensity exercise and the recovery period, but becomes less consistent during high-intensity exercise, making this app suitable for use during indoor activities of low to moderate intensity. Level of evidence Il; Diagnostic Studies - Investigating a diagnostic test.
\end{abstract}

Keywords: Validation, software; Heart rate; Smartphone; Exercise.

\section{RESUMO}

Objetivo: O número de pessoas que participam em atividades esportivas de lazer e competições amadoras aumentou acentuadamente nos últimos anos. Os aplicativos gratuitos para monitoramento da frequência cardiaca para smartphone estão disponíveis para uso; no entanto, as informações sobre sua precisão durante o exercício ainda são limitadas. Assim, nosso objetivo foi validar o aplicativo para monitoramento da frequência cardíaca para smartphone durante exercícios em esteira em indivíduos saudáveis. Métodos: Estudo experimental prospectivo que testou um aplicativo gratuito para monitoramento da frequência cardíaca "INSTANT HEART RATE: AZUMIO". Vinte e sete participantes saudáveis foram solicitados a realizar a tarefa em esteira em quatro diferentes cargas de trabalho: caminhada a $3,0 \mathrm{~km} / \mathrm{h}$, caminhada rápida a $5,0 \mathrm{~km} / \mathrm{h}$, jogging a $7,0 \mathrm{~km} / \mathrm{h}$ e corrida a 9,0km/h. Os participantes realizaram os exercícios por 3 minutos para cada carga de trabalho, e a frequência cardíaca foi registrada usando o aplicativo para smartphone e ECG em repouso, durante o período de exercício e recuperação a cada intervalo de 60 segundos. Resultados: A frequência cardíaca medida pelo aplicativo gratuito para smartphone em repouso, caminhada a 3,0 km/h, caminhada rápida a 5,0 km/h, jogging a 7,0 km/h e fase de recuperação foi precisa, com coeficiente de correlação $\geq 0,95$ e erro padrão da estimativa $<1$ bpm. No entanto, os valores de correlação durante a execução a 9,0 km/h foram incompatíveis e o erro padrão da estimativa foi > 5 bpm. Conclusão: O aplicativo gratuito para smartphone que testamos estima com precisão a frequência cardíaca em repouso, durante o exercício de baixa a moderada intensidade e o período de recuperação, mas torna-se menos preciso durante exercícios de alta intensidade, tornando este aplicativo adequado para uso em atividades internas de intensidade baixa a moderada. Nível de evidência ll; Estudos Diagnóstico - Investigação de teste diagnóstico.

Descritores: Validação de software; Frequência cardíaca; Smartphone; Exercício.

\section{RESUMEN}

Objetivo: El número de personas que participan en actividades deportivas recreativas y competiciones de aficionados ha aumentado notablemente en los últimos años. Las aplicaciones gratuitas para monitorización de la frecuencia cardíaca para smartphones están disponibles para uso; sin embargo, la información sobre su precisión durante el ejercicio todavía es limitada. Por lo tanto, nuestro objetivo fue validar la aplicación gratuita para monitorización de la frecuencia cardíaca para smartphones durante ejercicios en cinta rodante en personas sanas. Métodos: Estudio experimental prospectivo que probó una aplicación gratuita para monitorización de la frecuencia cardíaca "INSTANT HEART RATE: AZUMIO". Se solicitó a 27 participantes sanos que realizaran la tarea en cinta rodante en cuatro cargas 
de trabajo diferentes: caminata a 3,0 km/h, caminata rápida a 5,0 km/h, "jogging" a 7,0 km/h y carrera a 9,0 km/h. Los participantes realizaron los ejercicios durante 3 minutos para cada carga de trabajo, y las frecuencias cardíacas se registraron utilizando la aplicación para smartphone y ECG en reposo, durante el período de ejercicio y recuperación a cada intervalo de 60 segundos. Resultados: La frecuencia cardíaca medida con la aplicación gratuita para smartphone en reposo, caminata a 3,0 km/h, caminata rápida a 5,0 km/h, "jogging" a 7,0 km/h y fase de recuperación fue precisa con coeficiente de correlación $\geq 0,95$ y el error estándar de estimación $<1$ bpm. Sin embargo, los valores de correlación durante la ejecución a 9,0 km/h fueron inconsistentes con error estándar de estimación >5 bpm. Conclusión: La aplicación gratuita para smartphones que probamos calcula con precisión la frecuencia cardíaca en reposo, durante el ejercicio de baja a moderada intensidad y el período de recuperación, pero se vuelve menos preciso durante ejercicios de alta intensidad, haciendo que esta aplicación sea adecuada para utilización en actividades internas de intensidad baja a moderada. Nivel de evidencia II. Estudios de diagnóstico - Investigación de una prueba de diagnóstico.

Descriptores: Validación de programas de computación; Frecuencia Cardíaca; Smartphone; Ejercicio.

\section{INTRODUCTION}

Physical inactivity has been identified as one of the causes for the rise of chronic conditions such as obesity, diabetes mellitus, heart disease and cancer, and subsequently the related healthcare cost. ' At present, the general population has been encouraged to be more engaged in regular exercise activities and this has led to marked increase in the number of people participating in leisure sports activities and amateur competitions. However, it is important to highlight the danger that can occur in individuals who exercises; sedentary individuals may overstress their bodies during the beginning of their exercise programs and the professional athletes may face the danger when they go through vigorous training. ${ }^{2}$ As a precaution, these groups of people are advised to check on their heart rate during exercise and keep it within defined guidelines.

Heart rate $(H R)$ monitoring is vital in exercise ${ }^{3}$ and the usage of target heart rate has been practiced for many years in exercise prescription ${ }^{4}$ in general and athlete populations. ${ }^{5}$ Notably, heart rate can provide essential physiological information such as activity intensity, energy consumption valuation and calculation of relative heart rate to the intensity of the workload of an individual, ${ }^{6}$ and these results are exclusively beneficial in planning for an optimal training intensities of an individual. In addition, heart rates recorded during exercise or immediately after exercise can provide information about cardiovascular fitness level and health, ${ }^{7}$ and recovery heart rate is useful in predicting future cardiac events and mortality in both healthy and clinic population. ${ }^{8}$

The most traditional technique of measuring heart rate is by manually feeling the pulse at the spot where an artery is close to the body surface. Even though this method is simple but it requires a little skill to locate the pulse and gently count the pulsation and subsequently rate it, but at times, it can be inaccurate especially when it is self-counted. ' However, over time a wide variety of heart rate monitoring devices have been developed, for instance the chest strap (transmitter) that communicates with a watch (receiver). This device has been validated and has proven to provide a consistent and reliable reading of heart rate at rest and during exercise., 3,10 This heart rate monitoring technology has helped both the exercise enthusiasts and professionals to measure the heart rate and to apply a proper heart rate intensity guide during exercise activities or exercise prescription. ${ }^{4}$

At present, there are many free heart rate apps available in the smartphone's application (app) store. The usage of these apps has become increasingly popular because they are easy to use and do not require any costly equipment or any skill to measure the heart rate. ${ }^{11}$ The requirement for heart rate measurement using the smartphone app is a phone with a camera equipped with flash and the quality of the camera does not has much influence of the HR reading. ${ }^{7}$ The smartphone heart rate app measures the heart rates using the principle of Photo-plethysmography (PPG) ${ }_{1}^{12}$ where it is based on the principles that the blood absorbs more light than the surrounding tissue and the presence of variations in the blood volume during diastole and systole will affect the transmission or reflection of light. 13,14 This HR app is specially designed for self-use by anyone, whereby the users just need to put their fingertip on the camera lens and the light emitting diode (LED) flashlight concurrently. The app will record the changes in the light that accompanying the arterial pulsation and process these changes as heart rates' reading and help the users to determine their beats per min within seconds. ${ }^{14}$

Most people nowadays own a smartphone and can use this free heart rate app readily. However, the study on validating this HR app during exercise in the healthy individual is still limited. ${ }^{14}$ Based on our review, we hypothesized that the free smartphone heart app is accurate in measuring heart rate during exercise, therefore in this study, we have asked active individuals to perform treadmill exercise and measured their heart rate using ECG and smartphone app simultaneously.

\section{METHODS}

\section{Study design}

This was a prospective experimental study. Twenty-seven (27) healthy participants, twenty-two (22) male, and five (5) female, who participate in regular weekly exercises enrolled for this study. The primary investigator invited individuals who attended sports medicine clinic to join in this study. All subjects approached, briefed and screened for any medical indication such as any underlying cardiovascular or cardiac arrhythmias, neurological, musculoskeletal or metabolic disease. Subjects who were on medications that can influence the cardiovascular system or recently sustained injuries excluded from the study. All subjects answered the physical activity readiness questionnaire (PAR-Q) and undergone complete physical examination. Only subjects with medical clearance permitted to proceed in this study, and signed the free and informed consent term. Research ethics approval attained from the University of Malaya Medical Centre, MECID 201715-4744. This study conducted in compliance with ethical principles outlined in the Declaration of Helsinki and Malaysian Good Clinical Practice Guideline.

\section{Apparatus and Intervention}

The smartphone (OPPO FIND 7A) used in this study was owned by the primary investigator and using the keyword "heart rate", one free heart rate app with higher number rating was downloaded from the app store which was 'INSTANT HEART RATE: AZUMIO Inc, USA'. Participants were instructed not to eat or drink anything other than water in three hours preceding visit and refrain from doing any strenuous physical activity for at least 24 hours before their visit. Participants were also instructed to wear comfortable sports attire and sports shoe. Upon arrival to the sports medicine clinic, participants'height, weight, body mass index (BMI) and body impedance analysis measured and recorded. Participants were 
asked to do light stretching prior the test. Following the light stretching, ECG electrodes (COSMED) were then applied. All participants were taught on how to put the index finger over the camera lens using moderate pressure until a stable heart reading was displayed.

The participants stand still on the treadmill (HP COSMOS) for three minutes. During the three minutes, heart rate measured via the smartphone app and ECG at a 60-second interval, and the value was recorded. This heart rate represented the participants resting heart rates. The participants performed the exercise on the treadmill at four different workloads. The workloads were; stage 1 walking at $2.0 \mathrm{mph}$, stage 2 walking at $3.5 \mathrm{mph}$, stage 3 jogging at $4.5 \mathrm{mph}$ and stage 4 running at $6.0 \mathrm{mph}$. Participants then performed the exercises for 3 minutes for each workload. During each workload, the heart rates were recorded at every 60-second interval using smartphone app and ECG. After completing stage 4, participants continued walking on the treadmill at a comfortable pace for 1 minute and then sat on a chair for 2 minutes, heart rate recorded at a 60-second interval, and this heart rate represented the recovery heart rate.

\section{Statistical analysis}

Sample size calculation was performed using $G$ power 3.1.9.2 software, t-Test (A priori: Effect size 0.5, a error 0.05 and Power 0.8) the total sample size needed was 27 . All data were analyzed using SPSS version 24. Shapiro-Wilk test used to check for normal distribution of all data due to small sample size. ECG heart rates were the gold standard. 10,15 All variables were normally distributed for both ECG and Smartphone app heart rates. Parametric test used for comparison between the variables, standard error of estimate values obtained and Pearson's correlation was analyzed. Level of significance was set at $p<0.05$.

\section{RESULTS}

Twenty-seven ( $n=27)$ participants were involved in this study, 81.48 $\%(n=22)$ males and $18.52 \%$ females $(n=5) .44 .4 \%$ of participants were Malays ( $n=12), 37.04 \%$ were Indians $(n=10)$ and $18.52 \%$ were Chinese $(n=5)$. The mean age for the subjects was $32.89 \pm 3.08$ years old, mean height $169.59 \pm 8.68 \mathrm{~cm}$, mean weight $73.44 \pm 12.67 \mathrm{~kg}$ and mean $\mathrm{BMl}$ of 25.78 \pm 3.55 .14 participants have normal BMl $\left(20 \mathrm{~kg} / \mathrm{m}^{2}-24.9 \mathrm{~kg} / \mathrm{m}^{2}\right)$, 9 participants were overweight $\left(25.0 \mathrm{~kg} / \mathrm{m}^{2}-29.9 \mathrm{~kg} / \mathrm{m}^{2}\right)$ and 4 participants were obese $\left(30.0 \mathrm{~kg} / \mathrm{m}^{2}-34.9 \mathrm{~kg} / \mathrm{m}^{2}\right)$. The frequency of exercise per week among the participants were two times per week $(n=4)$, three times per week $(n=11)$, four times per week $(n=8)$ and five times per week $(n=4)$.

As shown in Table 1, we found that at minute 0 and minute 7, there was no mean difference between ECG and smartphone app. Meanwhile the $p$-value $<0.05$ in all stage except minute 12 in stage 4 . These findings showed that the smartphone app heart rate was equal to ECG heart rate in almost all stage. Meanwhile, the standard estimation error (SEE) values were noted to be $<1$ beat in all stage except for stage 4 where the SEE was $<5$ beats in minute 12 and $>5$ beats in minute 13 and 14 .

Findings in Table 2 showed the correlation coefficient value ( $r$ ) for $\mathrm{HR}$ measured by the free smartphone app were highly correlated in all stage $(r) \geq 0.95$ and $p<0.05$, except for stage 4 while running at $6 \mathrm{mph}$ (12-14 minute) the correlation values ( $r$ ) were inconsistent. At minute 12 the HR measured by the free smartphone app showed significant strong correlation $(r) \geq 0.95$ and $p<0.05$, but at minute 13 and 14 , the HR measured by the free smartphone app was poorly correlated with HR ECG where $(r) \leq 0.90$ and $p>0.05$.

\section{DISCUSSION}

Heart rate monitoring has been used as a training tool since a few decades ago and ever since many validated user-friendly portable heart rate monitors have been developed. ${ }^{2}$ Even though ECG is the gold standard for measuring heart rate, however, it is not practical
Table 1. Analysis of heart rate measured by ECG and Smartphone App during the treadmill test. Heart rate expressed in mean \pm SD. Mean different and standard estimation error (SEE) values were calculated.

\begin{tabular}{|c|c|c|c|c|c|}
\hline Stage of exercise & \begin{tabular}{|c|} 
Smartphone \\
App \\
Mean \pm SD
\end{tabular} & $\begin{array}{c}\text { ECG } \\
\text { Mean } \pm \text { SD }\end{array}$ & $\begin{array}{c}\text { Mean } \\
\text { Different }\end{array}$ & \begin{tabular}{|c|} 
Standard \\
estimation \\
error (SEE)
\end{tabular} & $p$-value \\
\hline \multicolumn{6}{|c|}{ Stage resting } \\
\hline $0 \mathrm{~min}$ & $77.81 \pm 11.86$ & $77.81 \pm 11.86$ & - & $0.001 \wedge$ & - \\
\hline $1 \mathrm{~min}$ & $77.59 \pm 13.05$ & $77.52 \pm 13.08$ & 0.074 & $0.270 \wedge$ & $0.161^{*}$ \\
\hline $2 \min$ & $78.00 \pm 12.28$ & $78.04 \pm 12.29$ & 0.037 & $0.196 \wedge$ & $0.327^{*}$ \\
\hline \multicolumn{6}{|c|}{ Stage 1 (2 $\mathrm{mph})$} \\
\hline $3 \mathrm{~min}$ & $87.41 \pm 10.71$ & $87.41 \pm 10.71$ & 0.037 & $0.001 \wedge$ & $0.327^{*}$ \\
\hline $4 \mathrm{~min}$ & $91.19 \pm 11.93$ & $91.19 \pm 11.93$ & 0.074 & $0.001 \wedge$ & $0.161^{*}$ \\
\hline $5 \mathrm{~min}$ & $92.59 \pm 12.93$ & $92.59 \pm 12.93$ & 0.037 & $0.001 \wedge$ & $0.574^{*}$ \\
\hline \multicolumn{6}{|c|}{ Stage 2 (3.5 $\mathrm{mph})$} \\
\hline $6 \mathrm{~min}$ & $100.52 \pm 12.42$ & $100.48 \pm 12.35$ & 0.037 & $0.185^{\wedge}$ & $0.327^{*}$ \\
\hline $7 \mathrm{~min}$ & $106.26 \pm 13.08$ & $106.26 \pm 13.08$ & - & $0.001 \wedge$ & - \\
\hline $8 \mathrm{~min}$ & $110.33 \pm 13.22$ & $110.30 \pm 13.18$ & 0.037 & $0.328 \wedge$ & $0.574^{*}$ \\
\hline \multicolumn{6}{|c|}{ Stage $3(4.5 \mathrm{mph})$} \\
\hline $9 \mathrm{~min}$ & $121.15 \pm 11.54$ & $121.15 \pm 11.54$ & 0.074 & $0.272^{\wedge}$ & $0.161^{*}$ \\
\hline $10 \mathrm{~min}$ & $130.63 \pm 12.51$ & $130.41 \pm 12.36$ & 0.222 & $0.901 \wedge$ & $0.207^{*}$ \\
\hline $11 \mathrm{~min}$ & $137.63 \pm 11.54$ & $137.41 \pm 11.73$ & 0.222 & $0.923 \wedge$ & $0.227^{*}$ \\
\hline \multicolumn{6}{|c|}{ Stage 4 (6 mph) } \\
\hline $12 \mathrm{~min}$ & $148.00 \pm 9.66$ & $147.26 \pm 10.20$ & 0.742 & $1.365 \wedge$ & 0.015 \\
\hline $13 \mathrm{~min}$ & $146.93 \pm 17.00$ & $154.78 \pm 9.71$ & 7.851 & 16.48 & $0.075^{*}$ \\
\hline $14 \mathrm{~min}$ & $153.30 \pm 22.93$ & $162.07 \pm 8.88$ & 8.778 & 22.830 & $0.095^{*}$ \\
\hline \multicolumn{6}{|c|}{ Stage Recovery } \\
\hline $15 \mathrm{~min}$ & $135.07 \pm 10.00$ & $135.11 \pm 9.943$ & 0.037 & $0.188^{\wedge}$ & $0.327^{*}$ \\
\hline $16 \mathrm{~min}$ & $120.07 \pm 8.22$ & $120.15 \pm 8.26$ & 0.074 & $0.392 \wedge$ & $0.327^{*}$ \\
\hline $17 \mathrm{~min}$ & $106.07 \pm 9.01$ & $105.89 \pm 9.01$ & 0.185 & $0.978 \wedge$ & $0.327^{*}$ \\
\hline
\end{tabular}

Table 2. Correlation coefficient ( $r$ ) and Pearson correlation between heart rate smartphone app and heart rate ECG. Heart rate ECG as the gold standard.

\begin{tabular}{|c|c|c|}
\hline Stage of exercise & $\begin{array}{l}\text { Correlation coefficient (r) } \\
\text { of Heart rate smartphone } \\
\text { app and Heart rate ECG }\end{array}$ & $\begin{array}{c}\text { Pearson Correlation } \\
\text { Sig. (2-tailed) }\end{array}$ \\
\hline \multicolumn{3}{|c|}{ Stage resting } \\
\hline $0 \mathrm{~min}$ & $1.000 \wedge \wedge$ & $0.001^{* *}$ \\
\hline $1 \mathrm{~min}$ & $1.000 \wedge \wedge$ & $0.001^{* *}$ \\
\hline $2 \mathrm{~min}$ & $1.000 \wedge \wedge$ & $0.001^{* *}$ \\
\hline \multicolumn{3}{|c|}{ Stage 1 (2 mph) } \\
\hline $3 \mathrm{~min}$ & $1.000 \wedge \wedge$ & $0.001^{* *}$ \\
\hline $4 \mathrm{~min}$ & $1.000 \wedge \wedge$ & $0.001^{* *}$ \\
\hline $5 \mathrm{~min}$ & $1.000 \wedge \wedge$ & $0.001^{* *}$ \\
\hline \multicolumn{3}{|c|}{ Stage $2(3.5 \mathrm{mph})$} \\
\hline $6 \mathrm{~min}$ & $1.000 \wedge \wedge$ & $0.001^{* *}$ \\
\hline $7 \mathrm{~min}$ & $1.000 \wedge \wedge$ & $0.001^{* *}$ \\
\hline $8 \mathrm{~min}$ & $1.000 \wedge \wedge$ & $0.001^{* *}$ \\
\hline \multicolumn{3}{|c|}{ Stage $3(4.5 \mathrm{mph})$} \\
\hline $9 \mathrm{~min}$ & $1.000 \wedge \wedge$ & $0.001^{* *}$ \\
\hline $10 \mathrm{~min}$ & $0.998 \wedge \wedge$ & $0.001^{* *}$ \\
\hline $11 \mathrm{~min}$ & $0.997 \wedge \wedge$ & $0.001^{* *}$ \\
\hline \multicolumn{3}{|c|}{ Stage 4 (6 mph) } \\
\hline $12 \mathrm{~min}$ & $0.990 \wedge \wedge$ & $0.001^{* *}$ \\
\hline $13 \mathrm{~min}$ & 0.310 & 0.116 \\
\hline $14 \mathrm{~min}$ & 0.217 & 0.277 \\
\hline \multicolumn{3}{|c|}{ Stage Recovery } \\
\hline $15 \mathrm{~min}$ & $1.000 \wedge \wedge$ & $0.001^{* *}$ \\
\hline $16 \mathrm{~min}$ & $0.999 \wedge \wedge$ & $0.001^{* *}$ \\
\hline $17 \mathrm{~min}$ & $0.994 \wedge \wedge$ & $0.001^{* *}$ \\
\hline
\end{tabular}

for individuals to monitor their heart rate in the natural environment using Holter ECG due to its cumbersome attachment of electrodes and wires. ${ }^{10}$ Unfortunately, the heart rate monitors are still considered difficult to use due to few issues, ${ }^{16}$ and they were also associated with the financial burden. ${ }^{10}$ Apart from that, many of these portable heart rate monitors require chest strap which is not appropriate to be used in individuals with sensitive skin or who are obese. ${ }^{1}$ However, with recent technology, many smartphones now can be used as heart rate monitor, where the smartphones can be installed with 
free heart rate app that can measure individuals' heart rate during exercise. ${ }^{14}$ Mitchell et al. believed that smartphone app is a reliable and valid tool to assess pulse rate in healthy individuals. ${ }^{17}$ Heart rate measurement using finger-tip showed comparable results and accurate concerning ECG ${ }^{18,19}$ and contacted PPG based apps have higher feasibility and better accuracy. ${ }^{13}$

In a previous study done by Spierer et al., they suggested that data recorded by heart rate monitor are valid if the correlation coefficients are $\geq 0.90$ and SEEs $\leq 5$ beats per minute (bpm). ${ }^{1,10}$ Yan et al. studied HR detection by a smartphone app at rest and after exercise in a healthy sample, and they found that the HR was accurate. ${ }^{20}$ However, in our study, we focus on validating the accuracy of a selected free smartphone heart rate app in measuring the heart rate of adult participants while performing different intensity of exercises and compares to ECG. Our findings showed that the heart rates measured using the free smartphone app at rest, during low to moderate exercise and recovery were accurate with $r \geq 0.95$ and SEEs $<1$ bpm, though, Zaman et al. reported that the smartphone app has $r=0.83$ in their study. ${ }^{19}$ The correlation values $(r)$ in this study for the smartphone HR measured were highly correlated during resting stage (0-2 minute), stage 1 walk at $2.0 \mathrm{mph}$ (3-5 minutes), stage 2 brisk walk at $3.5 \mathrm{mph}$ (6-8 minutes), stage 3 slow jogging at 4.5 mph (9-11 minutes) and recovery stage (15-17 minutes) with $(r) \geq 0.95$. However, the correlation values ( $r$ ) for stage 4 which was running at 6 mph (12-14 minute) were inconsistent, suggesting that the HR monitoring using smartphone app at this stage was not accurately measured.

However, from our observation in this present study, we noticed that as the intensity of exercise increases from moderate to high intensity the accuracy of heart rate measurement deteriorated. There was a noticeable issue with the free smartphone app and its ability to collect HR data at high-intensity activities where many participants had difficulties in maintaining the hold of the tip of their finger on the smartphone camera during the treadmill exercise. As the intensity of exercise increased, they felt more challenging to hold the tip of their finger on the smartphone camera. We also noted that there were instances where the free smartphone app could not record HR data accurately (fluctuating values) during running at $6 \mathrm{mph}$, mainly when there was excessive hand movement present. ${ }^{18}$ Apart from that, this inaccuracy may well originate from sweating and other artifacts during exercise. ${ }^{11}$

These findings were similar to a recent study done by Lee et al., where they tested the accuracy of a smartphone application in ischemic heart disease's patients, and they concluded that the accuracy of measured
HR from a smartphone was almost overlapped with the measurement from the Holter monitor in resting stage and recovery stage, but measurements error increased as the exercise intensity increased. ${ }^{21}$ This issue was also seen in a study using HR wrist-watch monitoring where it did provide valid $\mathrm{HR}$ readings at rest and during walking and light jogging but lose ability at higher treadmill speed. ${ }^{3}$

Although the findings are encouraging, few limitations that have been noted in this study; these include an unequal gender distribution and a small number of subjects involved in this study which may not represent the general population. Moreover, the free smartphone heart rate app used in this study was tested only on healthy individuals, the effect of underlying diseases such as peripheral vascular disease, skin diseases, abnormal blood pressure and autonomic nerve disorder which may affect the measurement of heart rate with PPG were not evaluated. Besides that, only one smartphone model used for data collection, which was iPhone $5 \mathrm{~s}$, the accuracy of free heart rate app with another model of smartphone should be tested too as it could prognosticate a better accuracy with their more advanced camera technology. Another limitation is that in this present study, we only examined on one free smartphone heart rate app and we did not compare it with other free smartphone heart rate apps; therefore, these findings cannot be generalized to all smartphone HR apps.

\section{CONCLUSION}

To summarize, the free smartphone app that we tested can accurately estimate the heart rate at rest, during low to moderate intensity exercise and recovery period. However, it becomes less consistent during high-intensity exercise due to some issues probably due to user-dependent, smartphone camera or the app itself. This free smartphone app is useful for measuring heart rate during low to moderate indoor exercise and physical activities. Moreover, with the widespread use of smartphone and expanding mobile broadband connectivity everyone can easily download this free smartphone HR app for self-use, and make this free heart rate app acts as an important tool in exercise monitoring. We hope that newer technology can rectify the issues that had occurred during high-intensity exercise.

\section{ACKNOWLEDGMENTS}

The authors would like to express their sincerest thanks to exercise-physiologists who helped with the data collection.

All authors declare no potential conflict of interest related to this article

AUTHORS' CONTRIBUTIONS: Each author made significant individual contributions to this manuscript. AM (0000-0003-4341-760X) and ZJ (0000-0002-4331-788X) participated in the study design, data collection, data analysis, and writing of the manuscript. ${ }^{*}$ ORCID (Open Researcher and Contributor ID).

\section{REFERENCES}

1. Spierer DK, Rosen Z, Litman LL, Fujii K. Validation of photoplethysmography as a method to detect heart rate during rest and exercise. J Med Eng. 2015;39(5):264-71.

2. Burke MJ, Whelan MV. The accuracy and reliability of commercial heart rate monitors. Br J Sports Med. 1987;21(1):29-32

3. Lee CM, Gorelick M. Validity of the Smart-health Watch to Measure Heart Rate During Rest and Exercise. Meas Phys Educ Exerc Sci. 2011:15(1):18-25.

4. Terbizan DJ, Dolezal BA, Albano C. Validity of Seven Commercially Available Heart Rate Monitors. Meas Phys Educ Exerc Sci. 2002;6(4):243-7.

5. Crouter SE, Albright C, Bassett Jr DR. Accuracy of polar $\$ 410$ heart rate monitor to estimate energy cost of exercise Med Sci Sports Exerc. 2004:36(8):1433-9.

6. Karvonen J, Vuorimaa T. Heart rate and exercise intensity during sports activities. Sports Med. 1988;5(5):303-11.

7. Papon MTI, Ahmad I, Saquib N, Rahman A. Non-invasive heart rate measuring smartphone applications using on-board cameras: A short survey. In Networking Systems and Security (NSysS), 2015 Internationa Conference on IEEE: 1-6.

8. Cole CR, Blackstone EH, Pashkow FJ, Snader CE, Lauer MS. Heart-rate recovery immediately after exercise as a predictor of mortality. N Engl J Med. 1999;341(18):1351-7.

9. Karvonen J, Chwalbinska-Moneta J, Saynajakangas S. Comparison of heart rates Measured by ECG and microcomputer. Phys Sportsmed. 1984;12(6):65-9.

10. Gregoski MJ, Mueller M, Vertegel A, Shaporev A, Jackson BB, Frenzel RM, et al. Development and validation of a smartphone heart rate acquisition application for health promotion and wellness telehealth applications. Int J Telemed Appl. 2012;2012:696324

11. Perdue KL, Westerlund A, McCormick SA, Nelson CA 3rd. Extraction of heart rate from functional near-infrared spectroscopy in infants. J Biomed Opt. 2014;19(6):067010.
12. Jonathan $\mathrm{E}$, Leahy $\mathrm{M}$. Investigating a smartphone imaging unit for photoplethysmography. Physio Meas. 2010;31(11):N79-83.

13. Coppetti T, Brauchlin A, Müggler S, Attinger-Toller A, Templin C, Schönrath F, et al. Accuracy of smartphone apps for heart rate measurement. Eur J Prev Cardiol. 2017;24(12):1287-93.

14. Ho CL, Fu YC, Lin MC, Chan SC, Hwang B, Jan SL. Smartphone Applications (Apps) for Heart Rate Measurement in Children: Comparison with Electrocardiography Monitor. Pediatr Cardiol. 2014;35(4):726-31.

15. Vandenberk T, Stans J, Van Schelvergem G, Pelckmans C, Smeets CJ, Lanssens D, et al. Clinical Validation of Heart Rate Apps: Mixed-Methods Evaluation Study. JMIR Mhealth Uhealth. 2017;5(8):e129.

16. Vanderlei LCM, Silva RA, Pastre CM, Azevedo FM, Godoy MF. Comparison of the polar S810i monitor and the ECG for the analysis of heart rate variability in the time and frequency domains. Braz J Med Biol Res. 2008;41(10):854-9.

17. Mitchell K, Graff M, Hedt C, Simmons J. Reliability and validity of a smartphone pulse rate application for the assessment of resting and elevated pulse rate. Physiother Theory Pract. 2016;32(6):494-9.

18. Nam Y, Kong Y, Reyes B, Reljin N, Chon KH. Monitoring of Heart and Breathing Rates Using Dual Cameras on a Smartphone. PLoS One. 2016;11(3):e0151013.

19. Zaman R, Cho CH, Hartmann-Vaccarezza K, Phan TN, Yoon G, Chong JW. Novel Fingertip Image-Based Heart Rate Detection Methods for a Smartphone. Sensors (Basel). 2017;17(2): E358.

20. Yan BP, Chan CK, Li CK, To OT, Lai WH, Tse G, et al. Resting and Postexercise Heart Rate Detection From Fingertip and Facial Photoplethysmography Using a Smartphone Camera: A Validation Study. JMIR Mhealth Uhealth. 2017;5(3):e33.

21. Lee ES, Lee JS, Joo MC, Kim JH, Noh SE. Accuracy of Heart Rate Measurement Using Smartphones During Treadmill Exercise in Male Patients With Ischemic Heart Disease. Ann Rehabil Med. 2017;41(1):129-37. 